\title{
Evaluation of Trace Elements in Adult Sickle Cell Anaemia Patients in Zaria, North Western Nigeria
}

\author{
Garba $N^{1}$, Ifeanyichukwu $\mathrm{OM}^{2 *}$, Amilo $\mathrm{GI}^{2}$ and Audu $\mathrm{I}^{3}$ \\ ${ }^{1}$ Department of haematology and Blood Transfusion, ABU Teaching Hospital, Zaria, Nigeria \\ ${ }^{2}$ Department of Immunology, Faculty of Medicine, Nnamdi Azikiwe University, Nnewi, Nigeria \\ ${ }^{3}$ Department of Haematology and Blood Transfusion, Federal Medical Centre Gusau, Nigeria
}

*Corresponding author: Ifeanyichukwu Ositadinma Martin, Department of Immunology, Faculty of Medicine, College of Health Sciences, Nnamdi Azikiwe University, Nnewi Campus, P.M.B. 5001, Anambra State, Nigeria, Tel: +2348037200407; E-mail: moifeanyi@yahoo.co.uk

Received date: Mar 01, 2016, Accepted date: Apr 07, 2016, Publication date: Apr 11, 2016

Copyright: (C) 2016 Garba N, et al. This is an open-access article distributed under the terms of the Creative Commons Attribution License, which permits unrestricted use, distribution, and reproduction in any medium, provided the original author and source are credited.

\begin{abstract}
Sickle cell anemia is a genetic disorder that is caused due to the inheritance of a mutant gene that encodes haemoglobin $\mathrm{S}(\mathrm{HbS})$. The amino acid glutamic acid is replaced with valine in the sixth position of b-globin chain. Protection of red cell membrane from free radical mediated oxidative stress is crucial to the management of SCD. Trace elements such as Copper, Zinc and Magnesium are of great benefit towards relieve of oxidative stress associated with red blood cell membranes. This study was carried out to evaluate some trace elements in adult sickle cell anaemia patientsattending sickle cell clinic, ABUTH-Zaria. Ethical clearance was obtained from ethics committee of Ahmadu Bello University Hospital Zaria, questionnaires were administered and informed consent was obtained from patients or their parents. One hundred and one (101) subjects aged 18 to 46 years participated in this study and these participants were divided into thirty five (35) confirmed sickle cell anaemia subjects in stable state (SS), thirty five (35) confirmed sickle cell anaemia subjects with history of vaso-occlusive crises in the last three months and (31) apparently healthy subjects ( $\mathrm{Hb} A A)$ as control subjects $(\mathrm{C})$. Haemoglobin electrophoresis was done using cellulose acetate method and serum copper, zinc and magnesium was analysed using Atomic Absorption Spectrophotometer (AAS) method. Serum copper, zinc and magnesium mean levels were significantly lower $(P=0.00)$ in SCA (SS and VOC) groups when compared with control group. No significance difference was observed in the mean levels of copper, zinc and magnesium in SS group when compared with VOC group $(P=0.36$, $P=0.89$ and $P=0.85$ ) respectively. The mean levels of trace elements were significantly lower in SCA groups than the control group. Evaluation of trace elements is suggested in the management of sickle cell anaemia.
\end{abstract}

Keywords: Sickle cell anaemia; Stable state; Vaso-occlusive crises; Serum copper; Zinc; Magnesium

\section{Introduction}

Sickle cell anemia is a condition resulting from mutant autosomal gene responsible for the synthesis of haemoglobin $\mathrm{S}(\mathrm{HbS})[1,2]$. The amino acid valine replaces glutamic acid in the sixth position of the $\beta$ globin chain $[3,4]$. These chains are of 146 amino acids long, the fault occurs at the sixth amino in the chains. The homozygous inheritance of this abnormality produces, haemoglobin SS and individuals with this genotype suffer from sickle cell anemia [5]. Sickle cell anaemia (SCA), a chronic debilitating disorder of genetic origin, is common in Africans and the Afro Caribbean. The disorder is characterized by varying clinical manifestations, referred to as crises among others [6]. Crises could be precipitated by a number of conditions like stress, extremes of temperature, infections - bacteria, viral, protozoa, particularly malaria, and a host of others [7-10].

Sickle cell anaemia is a public health problem in Africa than any other continent in the world and it affects about $2 \%$ of Nigerian population [11].

Trace elements are important in red blood cell maintenance, body growth and development [12,13]. Trace elements are pharmacologically beneficial and toxic, thus the need for monitoring of the dosage [14]. People with sickle cell disease suffer from trace elements deficiency and higher rates of nutrients deficiency may be due to increased needs of many nutrients in sickle cell patients [15]. There is increased turnover of hemopoietic cells due to chronic hemolysis and cell death leading to tremendous red marrow expansion. These conditions lead to hyper-metabolic rate and increases in nutrient and energy demand [16].

The global use of trace elements in health care delivery system has taken central stage due to the realization of their importance in disease management. Protection of red cell membrane from free radical mediated oxidative stress is crucial to the management of SCD. Trace elements play an important role in maintaining red cell membrane integrity and function [13].

This study was carried out to evaluate trace elements in sickle cell anaemia patients and compare findings with steady state and vasoocclusive crises in sickle cell anaemia.

\section{Methodology}

This study was conducted amongst sickle cell anaemia patients attending haematology clinic of Ahmadu Bello University Teaching Hospital (ABUTH) Zaria between September to November 2014. Only confirmed HbSS adult patients' attending sickle cell clinic, HbSS patients in steady or stable condition and those that had crises in the preceding three months and subjects that were not transfused in the last three months were included in the study. Patients with 
Page 2 of 4

haemoglinopathies other than sickle cell anaemia, patients who were transfusion dependent and those who receive transfusion in the last three months, patients on iron supplementation and unwillingness of the patients were excluded from the study. A total of 101 subjects (18-46 years) comprising of 70 subjects with sickle cell anaemia (SCA) and 31 apparently individuals with HbAA genotype were recruited into the study as control subjects (C). The SCA subjects comprised of 35 subjects in steady state (SS) and 35 subjects with vaso-occlusive crises (VOC). Twenty five (25) subjects had VOC in the last one month, eight (8) subjects had VOC in the last two months and two (2) subjects had VOC in the last three months. Control samples were obtained from interns and students on attachment. Questionnaires were administered to the participants and informed consent was obtained from all of them. All the patients were on routine tablets used in the sickle cell clinic; folic acid, paludrine and vitamin B complex tablets and none of them was on hydroxyurea because of the impact it could have on the result of the patient. Blood samples $(4 \mathrm{ml})$ were collected from all the subjects in the study groups. Serum samples were separated and stored at $-20^{\circ} \mathrm{C}$ until ready for analysis.

\section{Laboratory Methods}

The haemoglobin phenotypes were determined using the cellulose acetate electrophoresis method [17]. Serum copper, zinc and magnesium were determined with flame atomic absorption spectrophotometer (AAS) using a direct method as described by Kaneko [18].

\section{Statistical Analysis}

Data obtained was analysed using SPSS (version 17). Results were expressed as mean \pm SD using ANOVA and Pearson's correlation and a $\mathrm{P}$ value of $<0.05$ was considered significant.

\section{Results}

Table 1 shows the age, sex and weight of the study subjects. The 101 subjects comprising of $35 \mathrm{HbSS}$ in steady state (SS), $35 \mathrm{HbSS}$ withvasoocclusive crises (VOC) and $31 \mathrm{HbAA}$ as control subjects (C). SS group comprised of 11 males and 24 females, VOC group comprised of 12 males and 23 females and the control group comprised of 21 males and 10 females giving a total of 44 males and 57 females. The overall mean age SS group was $23.94 \pm 5.83$; VOC group was $24.63 \pm 6.63$ and control group $25.55 \pm 5.33$. Also, the overall mean weight of SS was $53.49 \pm 8.79$, VOC was $50.57 \pm 6.99$ and control was $58.19 \pm 7.55$.

As shown in Table 2, SCA groups (SS and VOC) had significantly ( $\mathrm{P}$ $=0.00$ ) lower mean serum copper, zinc and magnesium compared with control group. The mean values of copper, zinc and magnesium of the SS and VOC groups did not showed any significant difference $(\mathrm{P}=$ $0.36, \mathrm{P}=0.89$ and $\mathrm{P}=0.86$ ) respectively. However, the mean value of copper was significantly lower $(\mathrm{P}=0.00)$ in SS compared to control group but no significant difference $(\mathrm{P}=0.06)$ existed between VOC and control group. The mean value of zinc was significantly lower $(\mathrm{P}=$ $0.00)$ in SS compared with control group and VOC $(\mathrm{P}=0.00)$ compared with control group.

The mean value of magnesium was significantly lower in SS compared with control group and also the mean value of magnesium in VOC was significantly lower than the control group $(\mathrm{P}=0.01$ and $\mathrm{P}$ $=0.03$ ) respectively.

In Table 3, significant positive correlations were observed between copper and zinc $(r=0.64$ and $P=0.00)$. Also, significant positive correlations were observed between magnesium and zinc $(r=0.61$ and $P=0.00)$. Equally, significant positive correlations were observed between and copper and zinc $(r=0.44$ and $\mathrm{P}=0.00)$.

\begin{tabular}{|l|l|l|l|l|}
\hline Group & Age (Years) & Male & Female & Weight \\
\hline HbS (SS) $(n=35)$ & $23.94 \pm 5.87$ & 11 & 24 & $53.49 \pm 8.79$ \\
\hline HbS (VOC) $(n=35)$ & $24.63 \pm 6.63$ & 12 & 23 & $50.57 \pm 6.99$ \\
\hline Control (C) $(n=31)$ & $25.55 \pm 5.33$ & 21 & 10 & $58.19 \pm 7.55$ \\
\hline
\end{tabular}

Table 1: Shows the mean age, sex and weight of the study groups.

\begin{tabular}{|c|c|c|c|}
\hline Group & Copper $(\mu \mathrm{g} / \mathrm{dL})$ & Zinc $(\mu \mathrm{g} / \mathrm{dL})$ & $\mathrm{Mg}(\mathrm{mmol} / \mathrm{L})$ \\
\hline SS $(n=35)$ & $120.03 \pm 12.19$ & $100.76 \pm 18.08$ & $0.60 \pm 0.10$ \\
\hline $\operatorname{VOC}(n=35)$ & $125.21 \pm 18.86$ & $102.83 \pm 20.94$ & $0.62 \pm 0.12$ \\
\hline$C(n=31)$ & $135.73 \pm 18.56$ & $125.44 \pm 15.12$ & $0.71 \pm 0.17$ \\
\hline$F(P)$ value & $7.43(0.00)^{*}$ & $18.02(0.00)^{*}$ & $6.42(0.00)^{*}$ \\
\hline SS vs VOC P-value & 0.36 & 0.89 & 0.85 \\
\hline SS vs C P-value & $0.00^{*}$ & $0.00^{*}$ & $0.01^{*}$ \\
\hline VOC vs C P-value & 0.06 & $0.00^{*}$ & $0.03^{*}$ \\
\hline
\end{tabular}

Table 2: Shows the mean \pm SD of copper, zinc and magnesium in the study groups using ANOVA and Post Hoc. 


\begin{tabular}{|l|l|l|l|}
\hline Trace elements & Mean \pm SD & r & P-value \\
\hline Cu vs $Z n(n=101)$ & $126.64 \pm 17.79$ vs $109.05 \pm 21.21$ & 0.64 & $0.00^{*}$ \\
\hline Cu vs $M g(n=101)$ & $126.64 \pm 17.79$ vs $0.64 \pm 0.14$ & 0.61 & $0.00^{*}$ \\
\hline Mg vs $Z n(n=101)$ & $0.64 \pm 0.14$ vs $109.05 \pm 21.21$ & 0.44 & $0.00^{*}$ \\
\hline "significant at $P<0.005$ & & \\
\hline
\end{tabular}

Table 3: Shows the relationship of Copper $(\mu \mathrm{g} / \mathrm{dL})$, Zinc $(\mu \mathrm{g} / \mathrm{dL})$, and $\mathrm{Mg}(\mathrm{mmol} / \mathrm{L})$ using Pearson's correlation.

\section{Discussion}

Trace elements are important in red blood cell maintenance, body growth and development and their deficiency have been observed in sickle cell disease [12,13]. There is increased turnover of hemopoietic cells due to chronic hemolysis and cell death leading to tremendous red marrow expansion. These conditions lead to hyper-metabolic rate and increase in nutrient and energy demand [16].

Copper is known to be essential in the proper functioning of different metal enzymes which include ceruloplasmin involved in iron metabolism [19]. Deficiency of copper is known to cause anaemia [20]. Studies have suggested that the copper containing enzyme, ceruloplasmin may have specific role, probably related to its function in mobilization of stored iron in the liver which makes iron available for haemoglobin synthesis [21]. However, it has been observed that in copper deficiency induced anaemia, in spite of elevated iron level in the liver, the rate of haemoglobin synthesis remain significantly reduced [22].

In this study, a significantly low serum copper level was observed from the comparison of sickle cell anaemia group with control group and this is in agreement with the report of the study by Arinola et al. [22] in Ibadan, low level of copper have been noted in sickle cell anaemia patients. However, it is contrary to work done by Bot et al. [23] and Nnodim et al. [24] which revealed a significantly elevated level of copper in sickle cell patients.

Zinc is known as an important nutrient for growth and development and plays an important role in iron metabolism [25]. The mechanism through which zinc exerts its effect in correcting anemia in SCD is not understood [26], but it is known that the proteins making up the cytoskeleton of cell membranes acquire some abnormal configurations and often get irreversibly damaged. Zinc prevents the formation of such irreversibly damaged sickle cells [25]. Furthermore, it has been proposed that the role of zinc in the management of sickle cell anemia centers on its calcium antagonism.

This work revealed a significantly low serum zinc level in sickle cell anaemia and this is in agreement with the report of Prasad and Cossack [27] and Prasad [26], Edamisan et al. [28], Idonije et al. [29], Bot et al. [23] and Manafa et al. [30].

Cellular dehydration occurs due to a loss of potassium and water, and is correlated with the polymerization process and increased presence of irreversibly sickled cells [31]. Low levels of total Magnesium in sickle cell erythrocytes have been associated with increased sickling due to propensity for red cell dehydration and hence, increased $\mathrm{HbS}$ polymerization [32,33]. It has been demonstrated that the dehydration is due to abnormally high red cell permeability and loss of potassium $\left(\mathrm{K}^{+}\right)$via atleast three loosely connected pathways, in which the relative contribution of each is not yet known. One of these pathways, the $\mathrm{K}-\mathrm{Cl}$ co-transport, is abnormally activated by low cell $\mathrm{Mg}^{2+}$ [32]. This causes rapid irreversible loss of $\mathrm{K}^{+}$and $\mathrm{Cl}^{-}$ions, with water following osmotically.

This work revealed a significantly low level of serum magnesium in sickle cell anaemia and this is in agreement with de Franceshi et al. [32] and Zehtabchi et al. [34].

In this study, there was no significant difference in the mean levels of copper, zinc and magnesium between SS and VOC groups. Lack of significant difference in the mean levels of copper, zinc and magnesium between SS and VOC groups might be attributed to increased dehydration and sickled red blood cell formation due to reduce levels of trace elements in sickle cell anaemia patients.

However, there was significant difference in the mean levels of copper, zinc and magnesium between SCA groups (SS and VOC) and control. This suggests that higher rates of nutrient deficiency may be due to increased needs of many nutrients in sickle cell patients.

\section{Conclusion}

The mean levels of copper, zinc and magnesium were significantly lower in SCA groups when compared with control. This suggests that higher rates of nutrient deficiency may be due to increased needs of many nutrients in sickle cell patients. Evaluation of trace elements is suggested in the management of sickle cell anaemia to reduce complications (red cell dehydration, irreversible red cell damage and anaemia) associated with sickle cell anaemia.

\section{References}

1. Old JM (2003) Screening and genetic diagnosis of haemoglobin disorders. Blood Rev 17: 43-53.

2. http://www.scaf.com.ng/scaf-volunteer-comments.html

3. Steinberg MH (2008) Sickle cell anemia, the first molecular disease: Overview of molecular etiology, patho- physiology, and therapeutic approaches. Scientific World Journal 8: 1295-1324.

4. Chirico EN, Pialoux V (2012) Role of oxidative stress in the pathogenesis of sickle cell disease. IUBMB Life 64: 72-80.

5. Erin LB (2011) Understanding growth failure in children with homozygous sickle-cell disease. J Pediatr Oncol Nurs 28: 67-74.

6. Bolarinwa RA, Akinola NO, Aboderin OA, Durosinmi MA (2010) The role of malaria in vaso-occlusive crisis of adult patients with sickle cell disease. J Med MedSci 1: 407-411.

7. Behrens RJ, Cymet TC (2000) Sickle cell disorder: evaluation, treatment, and natural history. Hospital Physician: 17-28.

8. Ambe JP, Fatunde JO, Sodeinde OO (2001) Associated morbidities in children with sickle-cell anaemia presenting with severe anaemia in a malarious area. Trop Doct 31: 26-27. 
Citation: Garba N, Ifeanyichukwu OM, Amilo GI, Audu I (2016) Evaluation of Trace Elements in Adult Sickle Cell Anaemia Patients in Zaria, North Western Nigeria. J Blood Disord Transfus 7: 347. doi:10.4172/2155-9864.1000347

Page 4 of 4

9. Driss A, Asare KO, Hibbert JM, Gee BE, Adamkiewicz TV, et al. (2009) Sickle cell disease in the post genomic era: a monogenic disease with a polygenic phenotype. Genomics Insights 2009: 23-48.

10. Vinay K, Abul AK, Nelson F, Jon A (2009) Robbins and Cotran Pathologic Basis of Disease, Professional Edition: Expert Consult - Online (Robbins Pathology). Elsevier Health. Kindle Edition: 33498-33499.

11. http://www.who.int/gb/ebwha/pdfifiles/WHA59/A59i9-en.pdf

12. Mahyar A, Ayazi P, Pahlevan AA, Mojabi H, Sehhat MR, et al. (2010) Zinc and copper status in children with Beta-thalassemia major. Iran J Pediatr 20: 297-302.

13. Okpuzor J, Okochi VI (2009) Micro-nutrients as theurapeutic tools in the management of sickle cell anaemia. African Journal of Biotechnology 7 : 416-420.

14. Burtis CA, Ashwood ER, Bruns DE (2008) Trace elements. Tietz Fundamentals of Clinical Chemistry. WB Saunders Philadelphia 25: 496-508.

15. Hyacinth HI, Gee BE, Hibbert JM (2010) The Role of Nutrition in Sickle Cell Disease. Nutr Metab Insights 3: 57-67.

16. Hibbert JM, Creary MS, Gee BE, Buchanan ID, Quarshie A, et al. (2006) Erythropoiesis and myocardial energy requirements contribute to the hypermetabolism of childhood sickle cell anemia. J Pediatr Gastroenterol Nutr 43: 680-687.

17. Adewuyi JO (2007) Companion to practical haematology. A manual for the practical haematology course in the medical undergraduate programme in developing countries. Klobex Academic Publishers: 47-52.

18. Kaneko JJ (1999) Clinical Biochemistry of Animals. (4thedtn) Kaneko JJ Edition Academic Press. Inc. New York: 932.

19. Jaiser SR, Winston GP (2010) Copper deficiency myelopathy. J Neurol 257: 869-881.

20. Halfdanarson TR, Kumar N, Li CY, Phyliky RL, Hogan WJ (2008) Hematological manifestations of copper deficiency: a retrospective review. Eur J Haematol 80: 523-531.

21. Klevay LM (2006) "Myelodysplasia," myeloneuropathy, and copper deficiency. Mayo Clin Proc 81: 132.

22. Arinola OG, Olaniyi JA, Akiibnu MO (2008) Evaluation of antioxidant level and trace element status in Nigerian sickle cell disease patients with plasmodium parasitaemia. Pakistan journal of Nutrition 7: 766-769.
23. Bot YS, Benjamin A, Nyango DY, Ventmack DT, Eunice CB, et al. (2013) Analyses of $\mathrm{Cu}$ and $\mathrm{Zn}$ in serum of sickle cell disease patients in Jos. African Journal of Biochemistry 1: 001-004.

24. Nnodim JK, Meludu S, Dioka CE, Christian EO, Augustine I, et al. (2014) Trace elements deficiency in patients with homozygous sickle cell disease. British Journal of Medicine \& Medical Research 4: 3878-3883.

25. Prasad AS (2002) Zinc deficiency in patients with sickle cell disease. Am J Clin Nutr 75: 181-182.

26. Zemel BS, Kawchak DA, Fung EB, Ohene-Frempong K, Stallings VA (2002) Effect of zinc supplementation on growth and body composition in children with sickle cell disease. Am J Clin Nutr 75: 300-307.

27. Prasad AS, Cossack ZT (1984) Zinc supplementation and growth in sickle cell disease. Ann Intern Med 100: 367-371.

28. Edamisan OT, Edem SD, Mbang AO, James KR (2011) Relationship between Painful Crisis and Serum Zinc Level in Children with Sickle Cell Anaemia. Anemia 2011: 7.

29. Idonije BO, Iribhogbe OI, Okogun GRA (2011) Serum trace element levels in sickle cell disease patients in an urban city in Nigeria. Nature and Science 9: 67-71.

30. Manafa PO, Okocha CE, Nwogbo SC, Chukwuma GO, Ihim AC, et al. (2013) The status of some trace elements in sickle cell homozygous and heterozygous subjects attending Nnamdi Azikiwe University Teaching Hospital NAUTH, Nigeria. Archives of Basic and Applied Medicine 1: 73-75.

31. Ballas SK (2002) Sickle cell anaemia: progress in pathogenesis and treatment. Drugs 62: 1143-1172.

32. De Franceschi L, Bachir D, Galacteros F, Tchernia G, Cynober T, et al. (1997) Oral magnesium supplements reduce erythrocyte dehydration in patients with sickle cell disease. J Clin Invest 100: 1847-1852.

33. De Franceschi L, Bachir D, Galacteros F, Tchernia G, Cynober T, et al. (2000) Oral magnesium pidolate: effects of long-term administration in patients with sickle cell disease. Br J Haematol 108: 284-289.

34. Zehtabchi S, Sinert R, Rinnert S, Chang B, Heinis C, et al. (2004) Serum ionized magnesium levels and ionized calcium-to-magnesium ratios in adult patients with sickle cell anemia. Am J Hematol 77: 215-222. 